\title{
Molecular pathogenesis of aging and cancer: are telomeres and telomerase the connection?
}

Aging and cancer research appear to be completely separate fields of scientific study, the only connection being that the incidence of cancer generally increases with age. Aging is a complex process and it is unlikely that any single mechanism will explain all or even most of the molecular and physiological changes that occur as we age. Cancer is also a complex process and while it is equally unlikely that a single mechanism will explain all the biochemical and molecular changes that occur during the development of cancer, a major goal has been the search for common pathways for the origin of most cancers.

A major tenet of the disposable soma theory of aging ${ }^{1}$ is that the amount of energy invested in maintaining the somatic tissues of an organism is limited to that required to live long enough to reproduce successfully. Thus, for each species there is a trade off between investment in the maintenance of somatic cells and investment in reproduction. In evolutionary terms, it is generally believed that the earliest metazoan cells became mortal via some gain of function. If this is correct then mortal cells should have additional function(s) with respect to immortal cells, and revert to immortality when they lose those functions. Thus a fundamental difference between germ and somatic cells is that somatic cells have acquired mortality by gaining new functions. The idea that germ cells are immortal and somatic cells are mortal is generally accepted. For example, mouse embryonic stem cells have an unlimited capacity for division. When injected into another embryo the cells can integrate into the germ line, so their progeny passes to the next generation. Cell mortality becomes established in somatic cells later in embryonic development. The disposable soma theory can also be considered an example of antagonistic pleiotropy, ${ }^{23}$ as optimisation of health in young animals during the period of reproductive fitness could produce unselected late consequences in the post-reproductive individual who escapes an early death from disease, accidents, etc. In addition to a decline in physiological functions with age, perhaps an indirect consequence of a limit to somatic cell growth in long lived species, is that the finite cellular growth potential (replicative senescence) may also be a temporary barrier against uncontrolled proliferation of potential tumour cells. ${ }^{45}$

There is substantial experimental support for the theory that cellular aging is dependent on cell division, and total cellular lifespan is measured by the number of population doublings or cell generations, not by chronological time. ${ }^{6}$ This means there is an intrinsic process(es) occurring during cell growth that culminates in the cessation of cell division. If age is determined by a programme or some kind of counting mechanism that controls the number of cell divisions before proliferation ceases, then it is important to determine and understand what this mechanism is in molecular terms. ${ }^{7}$ During the past few years, there has been mounting evidence for the progressive loss of the telomeric ends of chromosomes during the aging process both in cell culture and in vivo. ${ }^{8-11}$ It is thought that the loss of telo- meres eventually induces antiproliferative signals that result in cellular senescence. ${ }^{12-14}$ A hypothesis gaining prominence is that the activation of telomerase, a ribonucleoprotein enzyme that is important in maintaining telomere length stability, is necessary for the sustained growth of most tumours. ${ }^{15-17}$ While studies of this area are still in their infancy, the relations between telomere shortening and aging, and how activation of telomerase may be necessary for cells to become immortal and progress to malignant cancer, has had much recent experimental support.

Overall, the telomere/telomerase hypothesis of aging and cancer can be summarised as follows:

- progressive telomere loss in cells is normal and may be the "clock" or timing mechanism that regulates cellular senescence

- cellular senescence occurs when telomeres are short, although the mechanism for this phenomenon has not been elucidated

- mutations occur in the telomerase repression pathway that cause the enzyme to upregulate or reactivate

- telomerase activity in cancer cells correlates with the stabilisation of telomere length and cellular immortalisation

- telomerase activity is necessary for the continued proliferation of cells and is a critical, perhaps rate limiting, step in cancer progression.

The pathways connecting telomere shortening, cellular senescence, telomerase expression, and cancer are certain to be subjects of intense investigation in the near future, and there are likely to be exceptions and refinements to the hypothesis. However, many recent advances such as the cloning of human telomerase RNA, ${ }^{18}$ it's catalytic protein subunit, ${ }^{19} 20$ a telomerase associated protein, ${ }^{21}{ }^{22}$ as well as the identification of telomere binding proteins, ${ }^{23}$ and the development of telomerase activity assays ${ }^{24}$ have provided molecular reagents to test some aspects of the hypothesis. The possibility that manipulating telomere length could change the rate of cellular senescence and affect the degenerative diseases of aging, or that inhibition of telomerase could provide a novel approach to cancer treatment, are exciting possibilities.

\section{JERRY W SHAY}

The University of Texas Southwestern Medical Center

Department of Cell Biology and Neurosciences,

5323 Harry Hines Boulevard,

Dallas, TX 75235-9039, USA

1 Kirkwood TBL. Evolution of aging. Nature 1977;270:301-4

2 Rose MR. The evolutionary biology of aging. Oxford: Oxford University Press, 1991.

3 Finch CE. Longevity, senescence and the genome. Chicago, University of Chicago Press, 1990.

4 Sager R. Senescence as a mode of tumor suppression. Environ Health Perspect 1991;93:59-62.

5 Campisi J. The biology of replicative senescence. Eur f Cancer 1997;33:7039 .

6 Hayflick L. The limited in vitro lifetime of human diploid cell strains. Exp Cell Res 1965;37:614-36.

7 Shay JW, Wright WE, Werbin H. Defining the molecular mechanism of human cell immortalization. Biochim Biophys Acta 1991;1072:1-7. 
8 Harley CB, Futcher BA, Greider CW. Telomeres shorten during aging of human fibroblasts. Nature 1990;345:458-60.

9 Hastie ND, Dempster M, Dunlop MG, Thompson AM, Green DK, Allshire RC. Telomere reduction in human colorectal carcinoma and with ageing. Nature 1990;346:866-8.

10 Lindsey J, McGill NI, Lindsey LA, Green DK, Cooke HJ. In vivo loss of telomeric repeats with age in humans. Mutat Res 1991;256:45-8.

11 DeLange T, Shiue L, Meyers RM, Cox DR, Naylor SL, Killery AM, et al. Structure and variability of human chromosome ends. Mol Cell Biol 1990; 10:518-27.

12 Harley CB. Telomere loss: mitotic clock or genetic time bomb? Mutat Res 1991;256:271-82.

13 Wright WE, Shay JW. Telomere positional effects and the regulation of cellular senescence. Trends Genet 1992;8:193-7.

14 Shay JW. Aging and cancer: are telomeres and telomerase the connection? Molecular Medicine Today 1995;1:378-84.

15 Shay JW, Wright WE. Telomerase activity in human cancer. Curr Opin Oncol 1996;8:66-71.

16 Shay JW, Bacchetti S. A survey of telomerase in human cancer. Eur f Cancer 1997;33:787-91.
17 Shay JW, Gazdar AF. Telomerase in the early detection of cancer. $\mathcal{f}$ Clin Pathol 1997;50:106-9.

18 Feng J, Funk WD, Wang S-S, Weinrich SL, Avilion AA, Chiu CP, et al. The RNA component of human telomerase. Science 1995;269:1236-41.

19 Nakamura TM, Morin GB, Chapman KB, Weinrich SL, Andrews WH Lingner J, et al. Telomerase catalytic subunit homologs from fission yeast and humans. Science 1997;277:955-9.

20 Meyerson M, Counter CM, Eaton EN, Ellisen LW, Steiner P, Caddle SD, $e$ al. hEST2, the putative human telomerase catalytic subunit gene, is upregulated in tumor cells and during immortalization. Cell 1997;90:785-95.

21 Harrington L, McPhail T, Mar V, Zhou W, Oulton R, Bass MB, et al. A mammalian telomerase-associated protein. Science 1997;275:973-7.

22 Nakayama JI, Saito M, Nakamura H, Matsuura A, Ishikawa F. TLP1-a gene encoding a protein component of mammalian telomerase is a novel member of WD repeats family. Cell 1997;88:875-84.

23 Chong L, Vansteensel B, Broccoli D, Erdjumentbromage H, Hanish J, Tempst $\mathrm{P}$, et al. A human telomeric protein. Science 1995;270:1663-7.

24 Kim N-W, Piatyszek MA, Prowse KR, Harley CB, West MD, Ho PLC, et al. Specific association of human telomerase activity with immortal cells and cancer. Science 1994;266:2011-15.

\section{Molecular Pathology-October 1997 contents}

\section{Reviews}

Target effector role of vascular endothelium in the inflammatory response: insights from the clinical trial of anti-TNF $\alpha$ antibody in rheumatoid arthritis

E Paleolog

Progeroid syndromes: probing the molecular basis of aging?

$D$ Kipling, $R$ G A Faragher

\section{Papers}

Extent of apoptosis in ovarian serous carcinoma: relation to mitotic and proliferative indices, p53 expression, and survival

M E Mc Menamin, A f O'Neill, E F Gaffney

Immunohistochemical detection of DNA topoisomerase I in formalin fixed, paraffin embedded normal tissues and in ovarian carcinomas

f A Holden, M P Rahn, $C \mathcal{F}$ folles, $S$ V Vorobyev, I B Bronstein

A differential PCR assay for the detection of c-erbB 2 amplification used in a prospective study of breast cancer

$B$ A fennings, $\mathcal{F}$ E Hadfield, S D Worsley, A Girling, $G$ Willis

Cyclin D1 and retinoblastoma protein expression in oesophageal squamous cell carcinoma $R$ Chetty, $S$ Chetty

Applications of capillary electrophoresis in DNA mutation analysis of genetic disorders $H$ Le, $D$ Fung, $R \mathcal{F}$ Trent

A rapid RT-PCR based method for the detection of BCR-ABL translocation F Y Sidorova, L B Saltykova, A A Lyschov, A Yu Zaritskey, K M Abdulkadyrov, $M$ N Blinov

Human cysteine dioxygenase type I (CDO-I; EC 1.13.11.20): $5^{\prime}$ flanking region and intron-exon structure of the gene

$D$ B Ramsden, A Kapadi, $N \mathcal{f} S$ Fitch, $M \mathcal{F}$ Farmer, P Bennett, A C Williams

\section{Short reports}

Whole genome amplification of single cells from clinical peripheral blood smears $C$ Beltinger, F Klimek, $K-M$ Debatin

A PCR-SSP method for detecting the Cys282Tyr mutation in the HFE gene associated with hereditary haemochromatosis

D Smillie

High resolution single strand conformation polymorphism analysis using formamide and ethidium bromide staining

TXie, S L Ho, OC KMa

\section{Miscellanea}

Books 